\title{
Outbreak of cutaneous form of avian poxvirus disease in previously pox-vaccinated commercial turkeys ${ }^{1}$
}

\author{
Bruna C. Ferreira ${ }^{2}$, Roselene Ecco ${ }^{3 *}$, Rodrigo M. Couto ${ }^{3}$, Humberto E. Coelho ${ }^{4}$, \\ Daise A. Rossi ${ }^{2}$, Marcelo E. Beletti ${ }^{2}$ and Paulo L. Silva ${ }^{2}$
}

\begin{abstract}
Ferreira B.C., Ecco R., Couto R.M., Coelho H.E., Rossi D.A., Beletti M.E. \& Silva P.L. 2018. Outbreak of cutaneous form of avian poxvirus disease in previously pox-vaccinated commercial turkeys. Pesquisa Veterinária Brasileira 38(3):417-424. Laboratório de Patologia, Departamento de Clinica e Cirurgia Veterinária, Escola de Veterinária, Universidade Federal de Minas Gerais, Av. Antonio Carlos 6627, Belo Horizonte, MG 31270-901, Brazil. E-mail: ecco@vet.ufmg.br

This study describes an outbreak of avian poxvirus disease in previously pox-vaccinated turkeys in Brazil. The turkeys had suggestive gross lesions of cutaneous avian poxvirus in the skin of the head and cervical area without changes in the flock mortality rates. In the slaughterhouse, 30 carcasses were removed from the slaughter line to collect tissue from cutaneous lesions for histological analyses and characterization of the virus. The virus was identified by conventional polymerase chain reaction (PCR) and subsequent gene sequencing. Acanthosis, hyperkeratosis, and hydropic degeneration were seen on skin histopathology. Eosinophilic intracytoplasmic inclusion bodies (Bollinger) on keratinocytes were observed in $46.6 \%$ of the samples. Avian poxvirus DNA was detected on PCR in $83.3 \%$ of the total samples. PCR associated with histopathology had $93.3 \%$ of positivity for avian poxvirus. In the phylogenetic study, samples show $100 \%$ matching suggesting that the outbreak occurred by a single viral strain and was different from those strains affecting other wild birds such as canaries and sparrows. A single mutation (Adenine for Guanine) was detected in our study's strain and in the strains of turkey, chickens, and vaccine strains published in GenBank. Also, when the sequence strain of the present study and sequences from GenBank of canarypox and sparrowpox strains were aligned, a Thymine was found replacing the Adenine or Guanine. The in ovo vaccination method as single-use in turkeys of this study apparently did not provide adequate protection against avianpox disease, but additional vaccination administered by wing-web when turkeys were 45-60 days old in the new flocks controlled the disease. In the subsequent year, new cases of this disease were not found. It was not possible to confirm the source of the virus strain, but infection with a field strain derived from chickens is one possibility, considering the poultry farm population in the area and biosecurity aspects. For wide characterization of avipoxvirus and differentiation among strains, the complete sequence of the viral genome is required.
\end{abstract}

INDEX TERMS: Avian poxvirus disease, avipoxvirus, fowlpox, pox-vaccinated, turkeys, pathology, fpv167 gene, sequencing, vaccine.

\footnotetext{
${ }^{1}$ Received on November 17, 2015.

Accepted for publication on January 31, 2017.

Pesquisa de Mestrado da primeira autora, com apoio CAPES e FAPEMIG.

${ }^{2}$ Laboratório de Biotecnologia Animal Aplicada, Faculdade de Medicina Veterinária, Universidade Federal de Uberlândia (UFU), Rua Ceará s/n, Bloco 2D, Sala 43, Campus Umuarama, Uberlândia, MG 38402-018, Brazil.

${ }^{3}$ Setor de Patologia Veterinária, Escola de Veterinária, Laboratório de Histopatologia, Universidade Federal de Minas Gerais (UFMG), Av. Presidente Antônio Carlos 6627, Pampulha, Belo Horizonte, MG 31270-901, Brazil. *Corresponding author: ecco@vet.ufmg.br

${ }^{4}$ Setor de Patologia Veterinária, Universidade de Uberaba (Uniube), Av. Nenê Sabino 1801, Bairro Universitário, Uberaba, MG 38055-500, Brazil.
}

RESUMO.- [Surto de bouba aviária na forma cutânea em perus comerciais previamente vacinados.] Este estudo descreve um surto de bouba aviária em perus previamente vacinados contra poxvirus aviário no Brasil. Os perus apresentaram lesões macroscópicas, sugestivas de bouba aviaria cutânea, na pele da cabeça e região cervical sem alteração nas taxas de mortalidade do lote. No abatedouro, 30 carcaças foram retiradas da linha de abate para coleta de dois fragmentos de pele com lesões para análise histológica e caracterização do vírus. A identificação do vírus foi 
realizada por PCR convencional e posterior sequenciamento. No exame histopatológico das lesões de pele, houve acantose, hiperqueratose e degeneração hidrópica. Corpúsculos de inclusão intracitoplasmáticos eosinofílicos (Bollinger) foram encontrados em $46,6 \%$ das amostras. A técnica de PCR detectou o DNA do vírus da bouba aviária em 83,3\% do total de amostras. PCR associado com a histopatologia resultou em 93,3\% de positividade para o vírus da bouba aviária. No estudo filogenético, as sequências resultaram em 100\% de identidade, sugerindo que o surto ocorreu por uma única estirpe de vírus diferenciada das outras estirpes que acometem canários e pardais. Uma única mutação (Adenina para Guanina) foi detectada nas estirpes deste estudo e nas sequências de perus, galinhas e estirpes vacinais publicadas no GenBank. Além disso, quando a sequência da estirpe do presente estudo e as sequências das estirpes de canarypox e sparrowpox foram comparadas, a Timina foi encontrada em substituição a Adenina ou Guanina. A vacinação in ovo em dose única utilizada nos perus deste estudo aparentemente não forneceu proteção adequada contra a doença causada pelo poxvirus aviário. Entretanto, a revacinação na membrana da asa em perus com 45-60 dias de idade dos novos lotes controlou a doença. No ano subsequente, novos casos desta doença não foram registrados. Não foi possível confirmar a origem da estirpe viral, mas estirpes de campo oriundas de galinhas seria uma possibilidade, considerando a população na área e os aspectos de biosseguridade. Para caracterização ampla do avipoxvirus e diferenciação entre as estirpes, a sequência completa do genoma viral é requerida.

TERMOS DE INDEXAÇÃO: Avipoxvirus, bouba aviária, perus, patologia, gene fpv167, sequenciamento, vacina.

\section{INTRODUCTION}

Poxvirus infections among avian species are caused by the genus Avipoxvirus, belonging to family Poxviridae (Tripathy \& Reed 2003). The avianpox disease is also called fowlpox or contagious epithelioma and affects both domestic and wild birds. In commercial birds, poxvirus can produce economic losses. Avipoxvirus can be transmitted by arthropod vectors or by direct contact with infectious virus particles (Tripathy \& Reed 2008).

Avianpox disease is characterized by formation of nodular proliferative skin lesions usually in the regions without feathers on the bird's body (cutaneous form) and/or fibrinonecrotic and proliferative lesions in the mucous membrane of the upper respiratory tract, mouth, and esophagus (diphtheric form) (Moço et al. 2008). A mixed type manifesting both forms has also been recorded (Tripathy \& Reed 2008). This disease is characterized by two phases: an initial response of the host cell with hyperplasia pronounced during the first $72 \mathrm{~h}$ and virus synthesis between 72 and 96 h post infection (Cheevers \& Randall 1968, Cheevers et al. 1968).

Although it is not a highly lethal disease and shows an atypical occurrence, avianpox disease is being frequently reported in avian wildlife in Brazil (Catroxo et al. 2009, Vargas et al. 2011, Pereira et al. 2014). In broilers, skin lesions caused by avian poxvirus were detected in carcasses of slaughtered birds from unvaccinated flocks (Fallavena et al. 2000). There are no recent studies using molecular characterization of poxvirus in Brazil, particularly in turkeys.

Avianpox reports are common in many countries and phylogenetic studies were described by Luschow et al. (2004), Jarmin et al. (2006), Manarolla et al. (2010), and Gyuranecz et al. (2013) with samples from the United States, Italy, Germany, and other countries. Molecular research correlated with clinical manifestations allow the identification and comparison of genetic strains by consulting a database of strains identified by infected species, country of origin, year of isolation, isolated type (cutaneous form, diphtheric, or mixed) and form of isolation (cultivation in embryonated eggs).

Live attenuated vaccines have been used to prevent disease in susceptible birds. The strains come from fowlpox of chickens or pigeons (Tripathy \& Reed 1997). However, the efficacy of these vaccines has been questioned worldwide, because in recent years, outbreaks have been reported in previously vaccinated turkeys (Odoya et al. 2006, Estrella-Tec et al. 2013).

An experimental study in vaccinated and unvaccinated turkeys for fowlpox revealed that vaccination did not influence the incidence of the disease but reduced the severity of clinical signs and mortality in young birds in the studied populations (Estrella-Tec et al. 2013).

Monitoring avianpox disease at slaughter was responsible for the increase in carcass condemnation related to this condition in turkeys from state of Minas Gerais, Brazil. In this study, we describe an avian outbreak of avianpox disease in previously vaccinated commercial turkeys.

\section{MATERIALS AND METHODS}

To obtain information related to the occurrence of avianpox disease in turkeys in the state of Minas Gerais, Brazil, data from official nosological maps constructed by the regional Federal Inspection Service were accessed. Turkeys (Meleagris gallopavo) from one farm only were examined and and samples from these turkeys were collected for histopathology and molecular study.

Sample collection. In June 2013, 115 day-old turkeys with an average of $15.44 \mathrm{~kg}$, from a farm in Indianapolis, Minas Gerais, were slaughtered. We selected 30 carcasses from the slaughter line of this flock to collect skin fragments with suggestive lesions of cutaneous fowlpox. A small piece of skin was pinched and pulled out using a scalpel and sterile tweezers. These fragments were sectioned to contain areas of the skin lesion and normal skin margin. Each section was divided in two portions: one was fixed in $10 \%$ buffered formalin for histological evaluation and another portion was stored at $-20^{\circ} \mathrm{C}$ until further molecular analysis.

Histopathological analysis. The fragments were fixed in 10\% buffered formalin for $48 \mathrm{~h}$ and then transferred to $70 \%$ ethanol. The tissues were dehydrated in increasing ethanol series, diaphanized in xylene, embedded in paraffin to obtain sections of $5 \mu \mathrm{m}$ thickness, stained with hematoxylin and eosin, and evaluated using light microscopy. Histopathological diagnosis of avian fowlpox was based on the observation of typical lesions associated with intracytoplasmic eosinophilic inclusion bodies (Tripathy \& Reed 2008). The inflammatory infiltration was graded according intensity in mild, moderate and marked. 
Molecular analysis. For DNA extraction, the modified protocol of Vogelstein \& Gillespie (1979) and Boom et al. (1990) was used.

Tissue samples were scraped using a 2.0 scalpel blade in a glass petri dish, and then added to a $1.5-\mathrm{mL}$ microtube and macerated with a pestle. Thereafter, the homogenate was added to $300 \mu \mathrm{L}$ of sodium iodide (NaI). For DNA adsorption, $40 \mu \mathrm{L}$ of silica (silicon dioxide, Sigma-Aldrich, St. Louis, MO, USA) was used. Then, the mixture was washed thrice in $500 \mu \mathrm{L}$ of ethanol and finally rinsed with $1 \mathrm{~mL}$ acetone. Extracted DNA was eluted in $40 \mu \mathrm{L}$ tris EDTA (TE) and then analyzed and quantified by atomic absorption at $260 \mathrm{~nm}$ in a spectrophotometer (Nanodrop ND- 1000, Thermo Scientific, Wilmington, USA.).

PCR for amplification of the gene fragment fpv167 (P4b locus) was performed using the following specific primers: 5'-CAGCAGGTGCTAAACAACAA-3' and 5'-CGGTAGCTTAACGCCGAATA-3' (Lawson et al. 2012); the product size was $578 \mathrm{bp}$. Each reaction was performed in a $25 \mu \mathrm{L}$ volume (PCR Master mix Promega) containing 200ng of DNA sample and $0.02 \mathrm{nmol}$ of each primer. Amplification was performed in a thermocycler under the following conditions: Initial denaturation at $94^{\circ} \mathrm{C}$ for $5 \mathrm{~min}$ followed by 45 cycles at $94^{\circ} \mathrm{C}$ for $1 \mathrm{~min}, 60^{\circ} \mathrm{C}$ for $1 \mathrm{~min}$ and $72^{\circ} \mathrm{C}$ for $1 \mathrm{~min}$, and a final extension at $72^{\circ} \mathrm{C}$ for $7 \mathrm{~min}$. The amplified PCR products were separated by electrophoresis on $1.5 \%$ agarose gel and visualized after staining with ethidium bromide under UV transillumination.

The amplified DNA products were extracted and purified from the agarose using the Invisorb ${ }^{\circledR}$ DNA Extraction Spin Kit, (B-Bridge, Santa Clara, CA, USA) according to manufacturer's recommendations. Each sample was bidirectionally sequenced in triplicate as per Sanger's method with capillary electrophoresis (ABI Taq DyeDeoxy Terminator Cycle Sequencing Kit version 3.1) on an automatic sequencer (ABI 3130 Genetic Analyzer).

For sequencing, four samples (P1, P6, P10, and P26) that yielded a single stronger band of correct size in the electrophoresis were selected. The sequencing reactions were performed with an initial denaturation step at $96^{\circ} \mathrm{C}$ for $1 \mathrm{~min} ; 30$ cycles at $96^{\circ} \mathrm{C}$ for $15 \mathrm{~s}$, $50^{\circ} \mathrm{C}$ for $15 \mathrm{~s}$, and $60^{\circ} \mathrm{C}$ for $4 \mathrm{~min}$; ending in a final step at $8^{\circ} \mathrm{C}$ indefinitely (SeqDNA Program). Next, this reaction product was precipitated with $40 \mu \mathrm{L}$ of $65 \%$ isopropanol, incubated at room temperature in the dark for $30 \mathrm{~min}$, and centrifuged at 14,000 rpm for $45 \mathrm{~min}$. The supernatant was removed, added to $500 \mu \mathrm{L}$ of $60 \%$ ethanol (Merck KGaA, Darmstadt, Germany), centrifuged at $14,000 \mathrm{rpm}$ for $10 \mathrm{~min}$, and the precipitate was dried in an oven at $95^{\circ} \mathrm{C}$ for $5 \mathrm{~min}$.

We analyzed the obtained sequences and created consensus sequences by using the SeqScap ${ }^{\circledR}$ software program (version 2.5 ). Mega program (version 5.0) was used to align sequences with the GenBank database (NCBI) using the BLASTn platform. Phylogenetic trees were generated by the neighbor-joining method with bootstrap 1000, Kimura two parameters.

The published sequences in Genbank used for comparison with the strain isolated from turkeys with avian fowlpox are shown in the results part.

\section{RESULTS}

The monitoring for avianpox disease occurrence started in January 2013 and continued for a year. In 2013, 16,830 turkeys were identified with suggestive lesions of avianpox disease at the slaughter. Turkeys from several farms on the region presented avianpox lesions, despite in ovo vaccination with live fowl pox virus. The monthly percentages of turkeys slaughtered with avianpox lesions ranged from $1.0 \%$ to $40.38 \%$, with high occurrence especially on the summer.

The examined turkeys presented lesions characteristic of the cutaneous form of fowlpox. Crusted and nodular coalescing lesions were found disseminated in the skin of the head (Fig.1 A and B) and cranial cervical region. No additional clinical signs or increasing mortality in the flock were recorded by the owner.

Histopathology of all sampled skin lesions showed hyperkeratosis, hyperplasia with hydropic degeneration of keratinocytes, and desquamation (Fig.2A). Intracytoplasmic eosinophilic inclusion bodies (Bollinger) in keratinocytes (Fig.2B) were found in $46.6 \%$ of samples. Skin lesions with predominance of necrosis (ulceration) of the entire epithelial layer with replacement by necrotic and keratin debris were observed in samples where inclusion bodies were not found.

In the dermis, there was multifocal to coalescing inflammatory infiltration of lymphocytes, forming aggregates (Fig.3). The classification of these inflammatory infiltrates was performed in three degrees considering the intensity
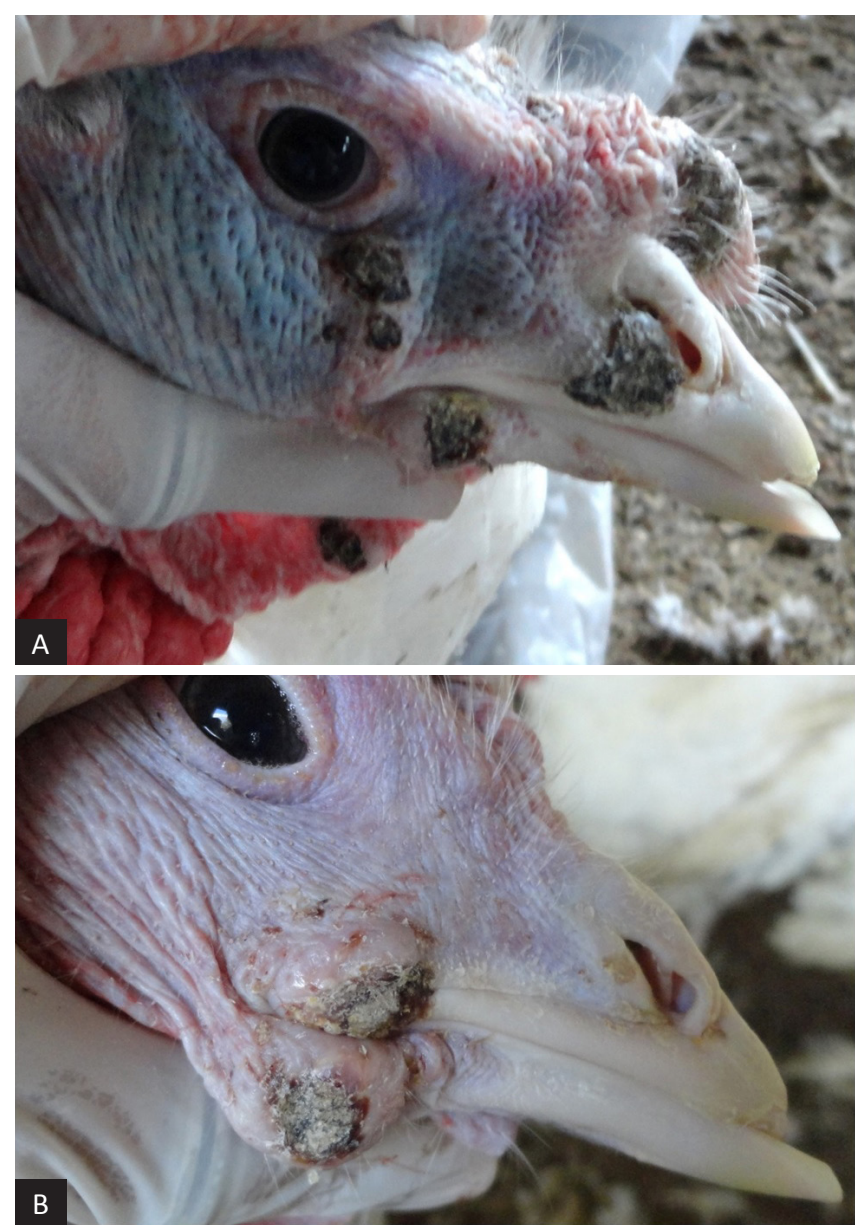

Fig.1. Commercial turkey naturally infected with avipoxvirus. $(\mathbf{A}, \mathbf{B})$ Nodular crusted lesions in the skin of snood, wattle, and beak commissure. 

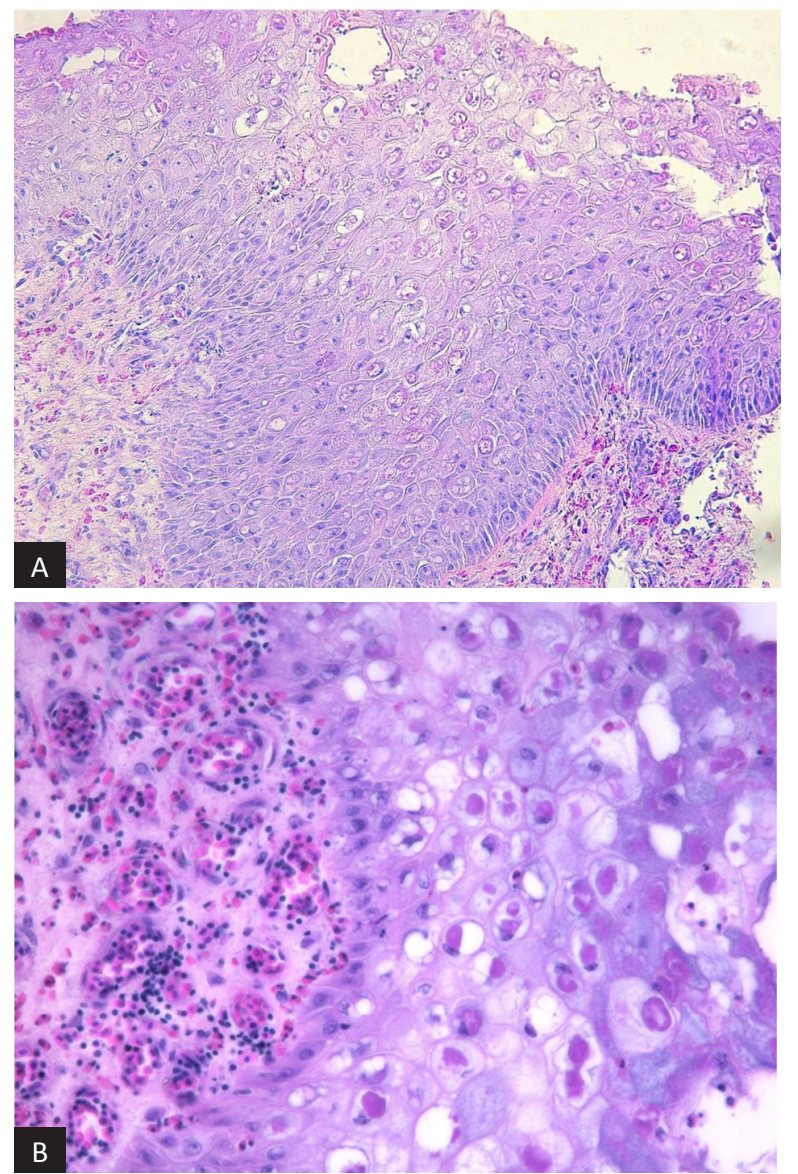

Fig.2. Skin of turkey naturally infected with avipoxvirus. (A) There is hyperplasia, hydropic degeneration of keratinocytes, vesicular formation, and desquamation of degenerative cells. Eosinophilic intracytoplasmic inclusions bodies are present in several keratinocytes. HE, obj.20x. (B) Magnification of panel A. Keratinocytes are enlarged with vacuolar hydropic degeneration associated with large eosinophilic intracytoplasmic inclusions bodies. In the dermis, there is hyperemia and mild lymphocytic infiltration. HE, obj.40x.

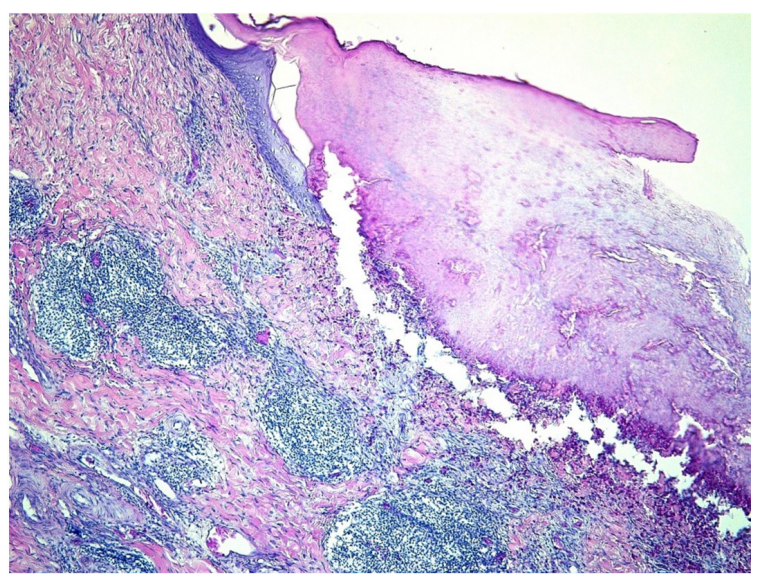

Fig.3. Skin of turkey naturally infected with avipoxvirus. Ulceration of epidermis and replacement with a layer of keratin and cells debris. In the dermis, there are multifocal to coalescing inflammatory infiltrating cells forming aggregates of lymphocytes. HE, obj.5x. and distribution on each skin section with lesions. In $56.6 \%$ of the samples, there was diffuse inflammatory infiltrate, $30 \%$ multifocal inflammatory infiltrate, $10 \%$ focal inflammatory infiltrate, and 3.3\% did not present inflammatory infiltrates (Table 1). In the skin of some birds, there were also erosions and ulcerations associated with heterophilic infiltration and bacterial colonies.

Histopathological examination associated with PCR allowed the confirmation of the disease caused by avian fowlpox in $93.3 \%$ of the samples analyzed in this study. Histopathology alone allows establishment of a definitive diagnosis for the disease in $46.6 \%$ of cases. Avipoxvirus was detected by PCR in $83 \%$ (25/30) of the samples. Negative results for avipoxvirus by PCR were detected in $17 \%(5 / 30)$ of the samples.

Sequencing of samples P1, P6, P10, and P26 showed that the region amplified was identical to the complete virus genome (complete fowlpox 4b). The Turkeypox sequences, Turkeypox GB134/01, Turkeypox PA213/07, fowlpox IPVDF/LSA/2012/01, fowlpox IPVDF/LSA/2012/02, fowlpox IPVDF/LSA/2012/03, fowlpox IPVDF/LSA/2012/04 (subtype turkeys), Cow Pox Chickenpox Mild Fort Dodge, Cow Pox Chickenpox Diftosec Merial, fowlpox Nobilis variole MSD (vaccines), fowlpox Hungary, Chickenpox CVL 174/4/04 and fowlpox HP (subtype chickens) also had 100\% identity with the sequence obtained (Fig.4). These strains belong to the subgroup A. This subgroup identification allows us to infer that the turkey samples from this study, which are separate from subgroup B that include pigeon, turkey and ostrich strains and subgroup $\mathrm{C}$, which include canary and sparrow strains, are not related to canary strains or strains found in other wild birds.

All samples evaluated in this study had Adenine (A) to Guanine (G) mutation at nucleotide 549 (Table 2).

Table 1. Samples with presence (P)/absence (A) of intracytoplasmic eosinophilic inclusion bodies, classification of lymphocytic and plasma cells infiltration and PCR results

\begin{tabular}{|c|c|c|c|c|c|c|c|c|c|c|c|}
\hline 兄 & 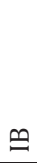 & 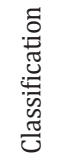 & 品 & 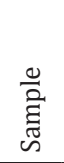 & $\bigoplus$ & 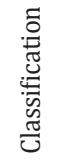 & يُ & 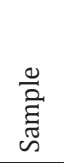 & $\bigoplus$ & 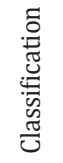 & يُ \\
\hline P1 & $\mathrm{P}$ & ++ & $\mathrm{P}$ & P11 & $\mathrm{P}$ & ++ & $\mathrm{P}$ & P21 & $\mathrm{P}$ & +++ & $\mathrm{P}$ \\
\hline P2 & - & + & $\mathrm{P}$ & P12 & - & ++ & $\mathrm{N}$ & P22 & $\mathrm{P}$ & ++ & $\mathrm{N}$ \\
\hline P3 & $\mathrm{P}$ & +++ & $\mathrm{P}$ & P13 & - & +++ & $\mathrm{P}$ & P23 & - & +++ & $\mathrm{P}$ \\
\hline P4 & $\mathrm{P}$ & +++ & $\mathrm{P}$ & P14 & - & +++ & $\mathrm{P}$ & P24 & $\mathrm{P}$ & +++ & $\mathrm{P}$ \\
\hline P5 & - & +++ & $\mathrm{N}$ & P15 & - & ++ & $\mathrm{P}$ & P25 & - & +++ & $\mathrm{P}$ \\
\hline P6 & $\mathrm{P}$ & +++ & $\mathrm{P}$ & P16 & - & +++ & $\mathrm{P}$ & P26 & - & +++ & $\mathrm{P}$ \\
\hline P7 & $\mathrm{P}$ & ++ & $\mathrm{N}$ & P17 & A & +++ & $\mathrm{P}$ & P27 & $\mathrm{P}$ & - & $\mathrm{P}$ \\
\hline P8 & A & + & $\mathrm{P}$ & P18 & $\mathrm{P}$ & ++ & $\mathrm{P}$ & P28 & $\mathrm{P}$ & ++ & $\mathrm{P}$ \\
\hline P9 & A & +++ & $\mathrm{P}$ & P19 & A & + & $\mathrm{P}$ & P29 & A & +++ & $\mathrm{P}$ \\
\hline P10 & $\mathrm{P}$ & +++ & $\mathrm{P}$ & P20 & $\mathrm{P}$ & ++ & $\mathrm{P}$ & P30 & A & +++ & $\mathrm{N}$ \\
\hline
\end{tabular}

IB = Intracytoplasmic eosinophilic inclusion bodies, $\mathrm{PCR}=$ polymerase chain reaction, $\mathrm{P}=$ positive, $\mathrm{N}=$ negative; - absent,+ mild, ++ moderate, +++ marked. 


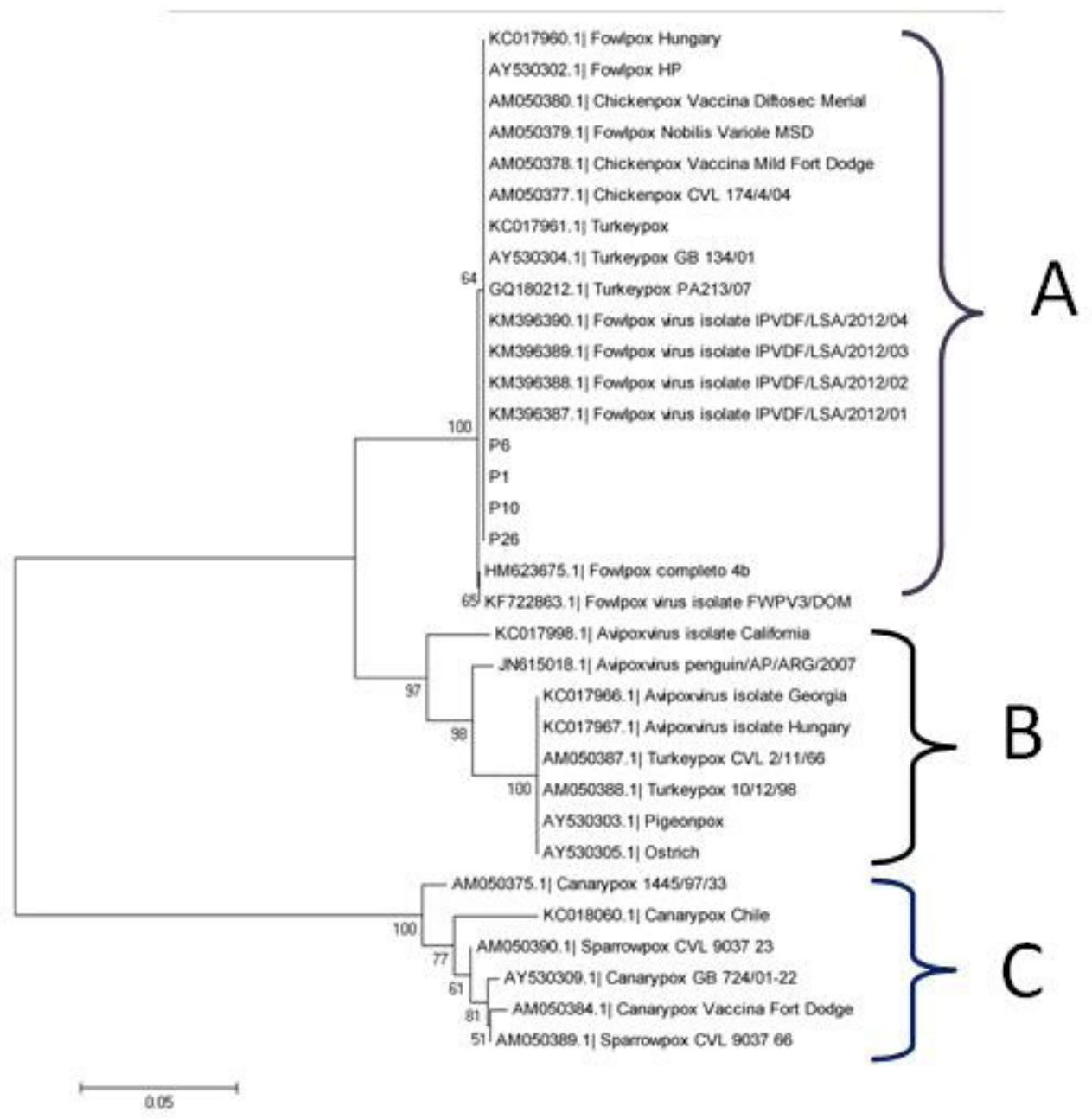

Fig.4. Phylogenetic tree generated from the concatenated sequence grouped and aligned to P4b nucleotide fragment of the fpv167 gene divided into three subgroups. Method: Neighbor-joining analysis with 1000 bootstrap replicates by using the Kimura 2-parameter model. (A) Chicken strain, (B) Pigeon strain, (C) Canary strain.

Table 2. Nucleotide sequence of positions 544 to 552 in the fpv167 gene of strains from Minas Gerais and other published avipoxvirus strains

\begin{tabular}{|c|c|c|c|c|c|c|c|c|c|}
\hline Samples & 544 & 545 & 546 & 547 & 548 & 549 & 550 & 551 & 552 \\
\hline HM623675.1| Fowlpox 4b gene & $\mathrm{T}$ & $\mathrm{A}$ & $\mathrm{T}$ & $\mathrm{T}$ & $\mathrm{C}$ & A & $\mathrm{C}$ & A & $\mathrm{C}$ \\
\hline P6 strain & . & . & . & . & . & $\mathrm{G}$ & . & . & . \\
\hline P1 strain & . & . & . & . & . & $\mathrm{G}$ & . & . & . \\
\hline P10 strain & . & . & . & . & . & G & . & . & . \\
\hline P26 strain & . & . & . & . & . & $\mathrm{G}$ & . & . & . \\
\hline JN615018.1| Avipoxvirus penguin/AP/ARG/2007 & . & . & . & . & . & . & . & . & $\mathrm{T}$ \\
\hline KC017966.1| Avipoxvirus Georgia & . & . & . & . & . & . & . & . & $\mathrm{T}$ \\
\hline KC017967.1| Avipoxvirus Hungary & . & . & . & . & . & . & . & . & $\mathrm{T}$ \\
\hline KC017998.1| Avipoxvirus California & . & . & . & . & . & . & . & . & $\mathrm{T}$ \\
\hline KF722863.1| Fowlpox FWPV3/DOM & . & . & . & . & . & . & . & . & . \\
\hline KM396387.1| Fowlpox IPVDF/LSA/2012/01 & . & . & . & . & . & $\mathrm{G}$ & . & . & . \\
\hline KM396388.1| Fowlpox IPVDF/LSA/2012/02 & . & . & . & . & . & $\mathrm{G}$ & . & . & . \\
\hline KM396389.1| Fowlpox IPVDF/LSA/2012/03 & . & . & . & . & . & $\mathrm{G}$ & . & . & . \\
\hline KM396390.1| Fowlpox IPVDF/LSA/2012/04 & . & . & . & . & . & G & . & . & . \\
\hline AM050387.1| Turkeypox CVL 2/11/66 & . & . & . & . & . & . & . & . & $\mathrm{T}$ \\
\hline AM050388.1| Turkeypox 10/12/98 & . & . & . & . & . & . & . & . & $\mathrm{T}$ \\
\hline GQ180212.1| Turkeypox PA213/07 & . & . & . & . & . & $\mathrm{G}$ & . & . & . \\
\hline AY530304.1| Turkeypox GB 134/01 & . & . & . & . & . & $\mathrm{G}$ & . & . & . \\
\hline
\end{tabular}


Table 2. Continued...

\begin{tabular}{|c|c|c|c|c|c|c|c|c|c|}
\hline Samples & 544 & 545 & 546 & 547 & 548 & 549 & 550 & 551 & 552 \\
\hline KC017961.1| Turkeypox & . & . & . & . & . & G & . & . & . \\
\hline AM050377.1| Chickenpox CVL 174/4/04 & . & . & . & . & . & G & . & . & . \\
\hline AM050378.1| Chickenpox Vaccina Mild Fort Dodge & . & . & . & . & . & G & . & . & . \\
\hline AM050379.1| FowlpoxNobilisVariole MSD & . & . & . & . & . & G & . & . & . \\
\hline AM050380.1| Chickenpox VaccinaDiftosecMerial & . & . & . & . & . & G & . & . & . \\
\hline KC017960.1| Fowlpox Hungary & . & . & . & . & . & G & . & . & . \\
\hline AY530302.1| Fowlpox HP & . & . & . & . & . & G & . & . & . \\
\hline AM050384.1| CanarypoxVaccina Fort Dodge & . & . & . & . & A & $\mathrm{T}$ & A & . & $\mathrm{T}$ \\
\hline AM050375.1| Canarypox 1445/97/33 & . & . & . & . & A & $\mathrm{T}$ & A & . & $\mathrm{T}$ \\
\hline AY530309.1| Canarypox GB 724/01-22 & . & . & . & . & A & $\mathrm{T}$ & A & . & $\mathrm{T}$ \\
\hline KC018060.1| Canarypox Chile & . & . & . & . & A & $\mathrm{T}$ & A & . & $\mathrm{T}$ \\
\hline AM050389.1| Sparrowpox CVL 903766 & . & . & . & . & A & $\mathrm{T}$ & A & . & $\mathrm{T}$ \\
\hline AM050390.1| Sparrowpox CVL 903723 & . & . & . & . & A & $\mathrm{T}$ & A & . & $\mathrm{T}$ \\
\hline AY530303.1| Pigeonpox & . & . & . & . & . & . & . & . & $\mathrm{T}$ \\
\hline AY530305.1| Ostrich & . & . & . & . & . & . & . & . & $\mathrm{T}$ \\
\hline
\end{tabular}

\section{DISCUSSION}

Histopathological lesions were consistent with the cutaneous form of avianpox in turkeys, confirming the clinical and macroscopic findings. Molecular analysis by PCR and sequencing confirmed the diagnosis of infection with avipoxvirus.

The result of monitoring carried out in the region in conjunction with the Federal Inspection Service, showed that the disease occurred frequently in 2013. Nevertheless, most cases occurred in the summer (data not shown). The prophylactic vaccination adopted in the region apparently did not prevent new cases of the disease in these birds during the monitoring year. Avianpox disease is widely distributed and has cyclical occurrence in endemic areas, especially in high-density areas of poultry production (Tripathy \& Reed 2008, Bernardino 2009) such as the outbreak area.

Some factors may be relevant in identifying the source of an outbreak. Scratches produced by the claws of other infected birds in the flock, presence of blood-sucking insects at the time of the outbreak (summer), and the possibility of virulence reversion of vaccine strain or type of vaccine strain should be considered (Fallavena et al. 1993, Tripathy \& Reed 2008, Bernardino 2009). The presence of mosquitoes is an important factor in the virus introduction in the region. In addition to the 11 species cited by Akey et al. (1981), Zylberberg et al. (2013) reported that Aedes aegypti and Culex quinquefasciatus, frequently found in Brazil, are also possible vectors of transmission of avipoxvirus. Singh et al. (2000) and Ramos et al. (2002) theorized a hypothesis about fowlpox outbreaks in previously vaccinated flocks concerning the emergence of strains containing reticuloendotheliosis virus genes integrated in the genome, which could possibly increase the virulence of these strains.

Usually the fowlpox is a self-limiting disease and has milder manifestations, as reported by Silva et al. (2009) in Brazilian free-range chickens. In the present case, a challenger viral strain might have disseminated to turkey flocks of the Triângulo Mineiro region. Bloodsucking insects and/or insufficient biosecurity measures and immunization (Tripathy
\& Reed 2008) were possibly involved in the introduction and dissemination of the virus to these turkey flocks.

The main gross lesions in this episode were nodular crusted lesions mainly found in the skin of head and neck, including caruncle, snood, wattle, eyelids, and beak commissure, consistent with previous avian poxvirus cutaneous disease reported in turkeys (Bernardino 2009, Hess et al. 2011). The clinical and gross presumptive diagnoses were confirmed by histopathological examination of lesions characterized by proliferative dermatitis containing eosinophilic intracytoplasmic inclusion bodies inside keratinocytes. These findings are consistent with the descriptions of Tripathy \& Reed (2008) and Hess et al. (2011). The eosinophilic intracytoplasmic inclusion bodies are pathognomonic for avianpox disease and could be present at $72 \mathrm{~h}$ post-infection in the epithelial tissue (Arhelger et al. 1962). Because of the absence of the inclusion bodies, the remaining $53.4 \%$ samples were diagnosed based on suggestive lesions of avianpox disease in association with PCR results. The absence of the characteristic findings such as intracytoplasmic inclusion bodies may be related to chronic injuries and extensive necrosis of the epidermis, aggravated by secondary bacterial infection.

The use of specific techniques such as PCR combined with histopathology allows a definitive diagnosis of various diseases. In this study, three samples (3/5) with PCR results negative for avipoxvirus had intracytoplasmic eosinophilic inclusion bodies, which is a lesion characteristic of the disease (Tripathy \& Reed 2008). Two remaining samples were negative in both histopathology and PCR tests. Probably, the sample collected had DNA virus lower than the detection threshold. Very small and extensively ulcerated samples with primary viral lesions replaced by secondary bacterial and cells debris could produce negative results (Tripathy \& Reed 2008, Parker et al. 2011). These results highlight the importance of tissue selection at moment of sampling to obtain reliable results.

In this study, considering the sequence of the fpv167 gene fragment, four samples showed $100 \%$ identity to each other suggesting that the outbreak occurred by a single virus strain. Phylogenetic studies by Jarmin et al. (2006) and Manarolla et al. 
(2010) found that the vast majority of avipoxvirus strains are grouped into three major subtypes, represented by chicken, psittacines, and canary strains.

The virus strain of this study was positioned near the turkeys' field strains identified in Brazil, called fowlpox IPVDF/LSA/2012/01, fowlpox IPVDF/LSA/2012/02, fowlpox IPVDF/LSA/2012/03, and fowlpox IPVDF/LSA/2012/04; all these were also grouped near the $4 \mathrm{~b}$ gene fragment of the complete genome of the chicken viruses, indicating $100 \%$ identity. The relationship with field or vaccine strains using the gene fragment sequenced was not possible because the fragment analyzed was short and similar for both strains.

The alignment of sequences of avipoxvirus gene in our study demonstrated that the virus origin is not from wild birds or passerines. The phylogenetic characterization established that the fragment fpv167 of the gene used was not sufficient for differentiating the strain in this study from field and vaccine strains from chickens and turkeys. Nevertheless, a single mutation (Adenine for Guanine) was detected in the present strain and in the strains of turkeys, chickens, and vaccine strains submitted to GenBank database. More studies are required to ascertain whether this mutation could influence some aspects of strain virulence and/or whether they belong to specific-host strains. Also, when the sequence strain of the present study and sequences from GenBank of canarypox and sparrowpox strains were aligned, a Thymine was found replacing the Adenine or Guanine. Although day-old turkey poults had been vaccinated with fowlpox vaccine at the hatchery (Sarma et al. 2015), the in ovo vaccination method as single-use in turkeys of this study apparently did not provide adequate protection against avianpox disease. According Tripathy \& Reed (2008), avianpox vaccination in turkeys should be performed intradermally about midway on the thigh when they are 2-3 months old. The wing-web method may create dry cutaneous pox lesions on the turkey's head (Tripathy \& Reed 2008). In the subsequent year to this outbreak, new episodes of this disease were not recorded. According to the veterinarian, improvement of the biosecurity measures and additional fowlpox vaccine administered by wing-web method when turkeys were 45-60 days old was adopted in an attempt to control the disease. Despite recommendations aforementioned for vaccine injection site, no avianpox lesions were reported again. The in ovo vaccination was routinely adopted in the region because the company obtained an automated egg injection machine for injecting vaccine into a plurality of eggs. Nevertheless, in farms or regions with high viral challenge, a second vaccine dose apparently is necessary to protect turkeys against avianpox disease.It was not possible to confirm the source of the virus strain, but infection with a field strain derived from chickens is one possibility, considering the farm poultry population in the area and biosecurity aspects. Nevertheless, the possibility of reversion to virulence of the live attenuated poxvirus vaccine strain cannot be excluded and complete sequence of the viral genome is required for complete characterization of avipoxvirus and differentiation among strains.

Acknowledgements.- We are thankful to the Foundation for Research of the State of Minas Gerais (FAPEMIG) grant APQ-02283-13. Fellowships were provided by "Coordenação de Aperfeiçoamento de Pessoal de Nível Superior" (CAPES), and "Conselho Nacional de Desenvolvimento Científico e Tecnológico" (CNPq). We also wish to thank the veterinarians of the Federal
Inspection Service and private company for collaboration in the collection of data and samples.

\section{REFERENCES}

Akey B.L., Nayar J.K. \& Forrester D.J. 1981. Avian pox in Florida wild turkeys: Culex nigripalpus and Wyeomyia vanduzeei as experimental vectors. J. Wildl. Dis. 17(4):597-599. http://dx.doi.org/10.7589/0090-3558-17.4.597. PMid:6121920.

Arhelger R.B., Darlington R.W., Gafford L.G. \& Randall C.C. 1962. An electron microscopic study of fowlpox infection in chick scalps. Lab. Invest. 11:814825. PMid:14013742.

Bernardino A. 2009. Bouba aviária, p.723-731. In: Berchieri Jr A., Silva E.N., Di Fábio J., Sesti L. \& Zuanaze M.A.F. (Eds), Doença das Aves. 2nd ed. Fundação Apinco de Ciência e Tecnologia Avícolas, Campinas.

Boom R., Sol C., Salimans M.M., Jansen C.L., Wertheim-van Dillen P.M. \& van der Noordaa J. 1990. Rapid and simple method for purification of nucleic acids. J. Clin. Microbiol. 28(3):495-503. PMid:1691208.

Catroxo M.H.B., Pongiluppi T., Melo N.A., Milanelo L., Petrella S., Martins A.M.C.P.F. \& Rebouças M.M. 2009. Identification of Poxvirus under transmission electron microscopy during outbreak period in wild birds, in São Paulo, Brazil. Int. J. Morphol. 27(2):577-585. http://dx.doi.org/10.4067/S071795022009000200043

Cheevers W.P. \& Randall C.C. 1968. Viral and cellular growth and sequential increase of protein and DNA during fowlpox infection in vivo. Proc. Soc. Exp. Biol. Med. 127(2):401-405. http://dx.doi.org/10.3181/00379727127-32700. PMid:4297158.

Cheevers W.P., O'Callaghan D.J. \& Randall C.C. 1968. Biosynthesis of host and viral deoxyribonucleic acid during hyperplastic fowlpox infection in vivo. J. Virol. 2(5):421-429. PMid:4301312.

Estrella-Tec J.E., Gutiérrez-Ruiz E.J., Ramírez-González S., Aranda-Cirerol F., Santos-Ricalde R. \& Puerto-Nájera J.L. 2013. Evaluation of a commercial vaccine against avian poxvirus in turkeys kept in the backyard system in the state of Yucatan, Mexico. Avian Pathol. 42(6):536-540. http://dx.doi. org/10.1080/03079457.2013.843159. PMid:24099591.

Fallavena L.C., Rodrigues N.C., Scheufler W., Martins N.R., Braga A.C., Salle C.T. \& Moraes H.L. 1993. Atypical fowl pox in broiler chickens in southern Brazil. Vet. Rec. 132(25):635. http://dx.doi.org/10.1136/vr.132.25.635. PMid:8394610.

Fallavena L.C.B., Moraes H.L.S., Salle C.T.P., Silva A.B., Vargas R.S., Nascimento V.P \& Canal C.W.2000. Diagnosis of skin lesions in condemned or downgraded broiler carcasses - a microscopic and macroscopic study. Avian Pathol 29(6):557-562. http://dx.doi.org/10.1080/03079450020016797. PMid:19184851

Gyuranecz M., Foster J.T., Dán Á., Ip H.S., Egstad K.F., Parker P.G., Higashiguchi J.M., Skinner M.A., Höfle U., Kreizinger Z., Dorrestein G.M., Solt S., Sós E., Kim Y.J., Uhart M., Pereda A., González-Hein G., Hidalgo H., Blanco J.M. \& Erdélyi K. 2013. Worldwide phylogenetic relationship of avian poxviruses. J. Virol. 87(9):4938-4951. http://dx.doi.org/10.1128/JVI.03183-12. PMid:23408635.

Hess C., Maegdefrau-Pollan B., Bilic I., Liebhart D., Richter S., Mitsch P. \& Hess M. 2011. Outbreak of cutaneous form of poxvirus on a commercial turkey farm caused by species fowlpox. Avian Dis. 55(4):714-718. http://dx.doi. org/10.1637/9771-050511-Case.1. PMid:22312999.

Jarmin S., Manvell R., Gough R.E., Laidlaw S.M. \& Skinner M.A. 2006. Avipoxvirus phylogenetics: identification of a PCR length polymorphism that discriminates between the two major clades. J. Gen. Virol. 87 (Pt 8):2191-2201. http:// dx.doi.org/10.1099/vir.0.81738-0. PMid:16847115.

Lawson B., Lachish S., Colvile K.M., Durrant C., Peck K.M., Toms M.P., Sheldon B.C. \& Cunningham A.A. 2012. Emergence of a novel avian pox disease in British tick species. PLoS One 7(11):e40176. http://dx.doi.org/10.1371/ journal.pone.0040176. PMid:23185231. 
Lüschow D., Hoffmann T. \& Hafez H.M. 2004. Differentiation of avian poxvirus strains on the basis of nucleotide sequences of $4 \mathrm{~b}$ gene fragment. Avian Dis. 48(3):453-462. http://dx.doi.org/10.1637/7111. PMid:15529967.

Manarolla G., Pisoni G., Sironi G. \& Rampin T. 2010. Molecular biological characterization of avian poxvirus strains isolated from different avian species. Vet. Microbiol. 140(1/2):1-8. http://dx.doi.org/10.1016/j. vetmic.2009.07.004. PMid:19646826.

Moço, H.F., Dias, L.C., Andolfato, L.H.M., Alves, M.L., Bronzatto, A. and Raya, D.A., 2008. Bouba Aviária. Revta Cient. Eletrôn. Med. Vet., vol. 4, no. 11.

Odoya E.M., Abegunde A., Agyogbo B.G., Omatainse S.O., Gwankat E. \& Okpara U.G. 2006. Outbreak of turkey pox disease in fowl pox vaccinated poults in Vom Plateau State of Nigeria. Afr. J. Clin. Exp. Microbiol. 7(2):136-138. http://dx.doi.org/10.4314/ajcem.v7i2.7443.

Parker P.G., Buckles E.L., Farrington H., Petren K., Whiteman N.K., Ricklefs R.E., Bollmer J.L. \& Jiménez-Uzcátegui G. 2011. 110 years of avipoxvirus in the Galapagos islands. PLoS One 6(1):e15989. http://dx.doi.org/10.1371/ journal.pone.0015989. PMid:21249151.

Pereira W.L.A., Gabriel Á.L.M., Monger S.G.B., Moraes L.A., Queiroz D.K.S. \& Souza A.J.S. 2014. Cutaneous tumor-like lesions associated with infection by avipoxvirus in a Dendrocygna autumnalis. Ciênc. Anim. Bras. 15(2):234238. http://dx.doi.org/10.1590/1809-6891v15i217202.

Ramos E., Coroas L., González M. \& Fernández A. 2002. Detección de secuencias pertenecientes al virus de la reticuloendoteliosis en el genoma de cepas vacunales y clones del virus de la viruela aviar. Revta Salud Anim. 24:134-141.

Sarma G., Kersting B.A. \& Spina G. 2015. Vaccination o 1-day-old turkey poults with fowl pox vaccine by subcutaneous rote. Avian Dis. 59(3):419-421. http://dx.doi.org/10.1637/11032-020515-ResNote.1. PMid:26478161.
Silva P.S., Batinga T.D.B., Sales T.S., Herval E.F.G., Ramos I., Maia P.C.C. \& Fernandes L.M.B. 2009. Fowlpox: identification and adoption of prophylactic measures in backyard chickens in Bahia, Brazil. Braz. J. Poult. Sci. 11:115-119.

Singh P., Kim T.J. \& Tripathy D.N. 2000. Re-emerging fowlpox: evaluation of isolates from vaccinated flocks. Avian Pathol. 29(5):449-455. http://dx.doi. org/10.1080/030794500750047207. PMid:19184837.

Tripathy D.N. \& Reed W.N. 1997. Pox, p.643-659. In: Thomas N.J., Hunter D.B. \& Atkinson C.T. (Eds), Diseases of Poultry. 10th ed. Iowa State University Press, Ames.

Tripathy D.N. \& Reed W.N. 2003. Pox, p.253-269. In: Saif Y.M., Barnes H.J., Glisson J.R., Fadly A.M., McDougald L.R. \& Swayne D.E. (Eds), Diseases of Poultry. 11th ed. Iowa State University Press, Ames.

Tripathy D.N. \& Reed W.N. 2008. Pox, p.291-308. In: Saif Y.M., Fadly A.M., Glisson J.R., McDougald L.R., Nolan L.K. \& Swayne D.E. (Eds), Diseases of Poultry. 12th ed. Blackwell Publishing, Ames, Iowa.

Vargas G.D., Albano A.P., Fischer G., Hübner S., Sallis S.E., Nunes C.F., Raffi M.B. \& Soares M.P. 2011. Avian pox virus infection in a common barn owl (Tyto alba) in southern Brazil. Pesq. Vet. Bras. 31(7):620-622. http:// dx.doi.org/10.1590/S0100-736X2011000700012.

Vogelstein B. \& Gillespie D. 1979. Preparative and analytical purification of DNA from agarose. Proc. Natl. Acad. Sci. USA 76(2):615-619. http://dx.doi. org/10.1073/pnas.76.2.615. PMid:284385.

Zylberberg M., Lee K.A., Klasing K.C. \& Wikelski M. 2013. Variation with land use of immune function and prevalence of avian pox in Galapagos finches. Conserv. Biol. 27(1):103-112. http://dx.doi.org/10.1111/j.15231739.2012.01944.x. PMid:23082926. 